OPEN

SUBJECT AREAS:

SMALL MOLECULES

PEPTIDES

DRUG DEVELOPMENT

Received

3 June 2014

Accepted

12 August 2014

Published

15 October 2014

Correspondence and requests for materials should be addressed to

Z.M.Y. lyangzm@ nankai.edu.cn) or D.D.

(dingd@nankai.edu.

$\mathrm{cn})$

\title{
Self-assembling choline mimicks with enhanced binding affinities to C-LytA protein
}

\author{
Yang Shi, Hao Zhou, Xiaoli Zhang, Jingyu Wang, Jiafu Long, Zhimou Yang \& Dan Ding
}

State Key Laboratory of Medicinal Chemical Biology, Key Laboratory of Bioactive Materials, Ministry of Education, College of Life Sciences, and Collaborative Innovation Center of Chemical Science and Engineering (Tianjin), Nankai University, Tianjin 300071, P. R. China.

Streptococcus pneumoniae (pneumococcus) causes multiple illnesses in humans. Exploration of effective inhibitors with multivalent attachment sites for choline-binding modules is of great importance to reduce the pneumococcal virulence. In this work, we successfully developed two self-assembling choline mimicks, Ada-GFFYKKK' and Nap-GFFYKKK', which have the abilities to self-assemble into nanoparticles and nanofibers, respectively, yielding multivalent architectures. Additionally, the best characterized choline-binding module, C-terminal moiety of the pneumococcal cell-wall amidase LytA (C-LytA) was also produced with high purity. The self-assembling Ada-GFFYKKK' and Nap-GFFYKKK' show strong interactions with C-LytA, which possess much higher association constant values to the choline-binding modules as compared to the individual peptide Fmoc-K'. This study thus provides a self-assembly approach to yield inhibitors that are very promising for reducing the pneumococcal virulence.

 he research on Streptococcus pneumoniae (pneumococcus) has been attracting increasing interest as the bacteria can cause illnesses ranging in severity from meningitis, septicaemia, and pneumonia to sinusitis and acute otitis media ${ }^{1-4}$. The pneumococci are characterized by their cell walls, which contain many teichoic acid units with multivalent phosphocholine groups 5 . These multivalent choline groups can be attached by a variety of surface-exposed choline-binding proteins, resulting in bacterial virulence such as cell-wall division and bacterial toxin release $\mathrm{e}^{6-8}$. The choline-binding proteins always contain characteristic choline-binding modules. One of the best characterized choline-binding modules is C-terminal moiety of the pneumococcal cell-wall amidase LytA (C-LytA), which consists of six loop- $\beta$-hairpin structures that together form a left-handed $\beta$ solenoid with four choline-binding sites ${ }^{9-11}$.

To reduce the pneumococcal virulence, one efficient approach is the treatment of the bacteria with exogenously choline-based inhibitors in order to competitively suppress the attachment of choline-binding proteins to the pneumococcal cell wall. By using this strategy, the pneumococci would grow into a long chain, which lead to abnormal bacterial division, inhibiting the bacterial toxin release and their spreading on the host tissue during infection ${ }^{12-14}$. It should be noted that the multivalent arrangement of choline groups on the cell wall of pneumococcus plays an essential role in their attachment to choline-binding proteins with high affinity and specificity. This is because multivalent choline groups can effectively match the tandem choline-binding sites in cholinebinding modules, whereas the interaction between one choline molecule and one single choline-binding site is weak $^{7,15,16}$. Therefore, many reported strategies for preparation of choline-based inhibitors were to employ scaffolds that can provide multivalent functional groups for choline decoration (e.g. choline dendrimer $)^{7,13}$. Although the currently available inhibitors have shown good effectiveness, more efficient ones are always highly desirable for further reducing the pneumococcal virulence, which motivate us to explore a new and simple strategy for fabricating multivalent architectures in order to realize enhanced binding affinity to the cholinebinding modules (e.g. C-LytA).

Recently, great interest has been focused on utilizing self-assembly rather than covalent scaffold synthesis to achieve multivalency, as the self-assembly approach has several advantages, such as simplified synthetic procedures, ease of incorporating multiple active units, tunability of nanostructure morphology as well as its characteristic responsive nature ${ }^{17-21}$. In this contribution, we designed and synthesized two choline mimicks, Ada-GFFYKKK' and Nap-GFFYKKK' (1 and 2 in Fig. 1, respectively), which can self-assemble into nanostructures with multivalent $K^{\prime}$ groups. $K^{\prime}$ is a derivative of $K$ by its quaternization. Due to the similar chemical 


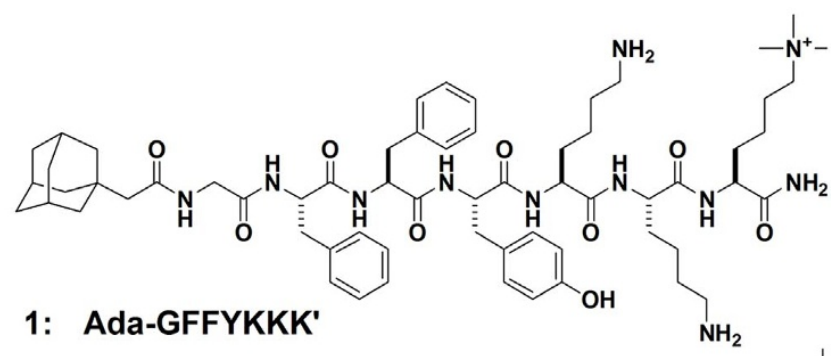

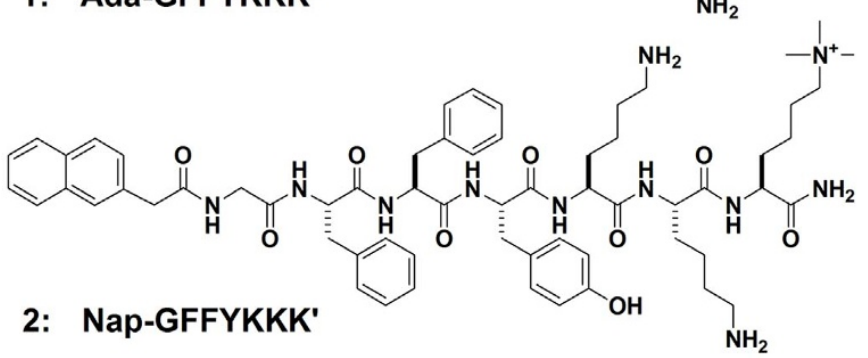

Figure $1 \mid$ Chemical structures of choline mimicks with possible selfassembling properties.

structure of $\mathrm{K}$ ' to choline, we expected that the multivalent $\mathrm{K}$ ' groups might efficiently match the tandem choline-binding repeats in $\mathrm{C}$ LytA. The isothermal titration calorimetry (ITC) results revealed that both self-assembling 1 and 2 exhibited far higher association constant with C-LytA as compared to Fmoc-K' itself. To the best of our knowledge, this is the first report on using $\mathrm{K}$ ' to replace choline for preparation of inhibitors that could specifically and very tightly bind to choline-binding modules. Furthermore, most of the currently available inhibitors were based on covalent scaffolds; rather limited work has focused on the exploration of inhibitors using the self-assembly approach. This study thus provides fundamental guidelines to yield new pneumococcal inhibitors by self-assembly, which will inspire more exciting work in this research field.

\section{Results}

Synthesis and characterization of choline mimicks. We have previously demonstrated that the peptides based on GFFY with naphthaline (Nap) and adamantane (Ada) as capping groups possess excellent self-assembly property ${ }^{22-24}$. Generally, peptides based on NapGFFY will self-assemble into nanofibers, while those based on AdaGFFY into nanofibers or nanospheres. We therefore planed to synthesize Ada-GFFYKKK' (1) and Nap-GFFYKKK' (2), and we imagined that they might self-assemble into different kinds of architectures. The two compounds were firstly synthesized by solid phase peptide synthesis (SPPS). The pure compounds were obtained by reverse phase high performance liquid chromatography (HPLC) in moderate yields. The purity and identity of 1 and $\mathbf{2}$ were characterized by ${ }^{1} \mathrm{H}$ NMR and HR-MS spectra, respectively (Supplementary Fig. S1 and S2 for 1; Supplementary Fig. S3 and S4 for 2).

Self-assembling properties of choline mimicks. The self-assembly behaviors of the two designed compounds were subsequently studied by dynamic light scattering (DLS) and transmission electron microscopy (TEM). The DLS results shown in Fig. 2A and 2B reveal that the critical micelle concentration (CMC) for 1 and 2 is 1.20 and $2.29 \mathrm{mmol} / \mathrm{L}$, respectively, suggesting that both compounds have similar self-assembly abilities. The morphology of the compounds after self-assembly in aqueous solution was also investigated by TEM. Fig. 2C and 2D show the TEM images of 1 and 2 in phosphate buffered saline (PBS, $\mathrm{pH}=7.4$ ) buffer when the compound concentrations are higher than their corresponding CMC values. Compound 1 upon self-assembly exhibits nanoparticle morphology with an average diameter of around $153 \mathrm{~nm}$ (Fig. 2C).
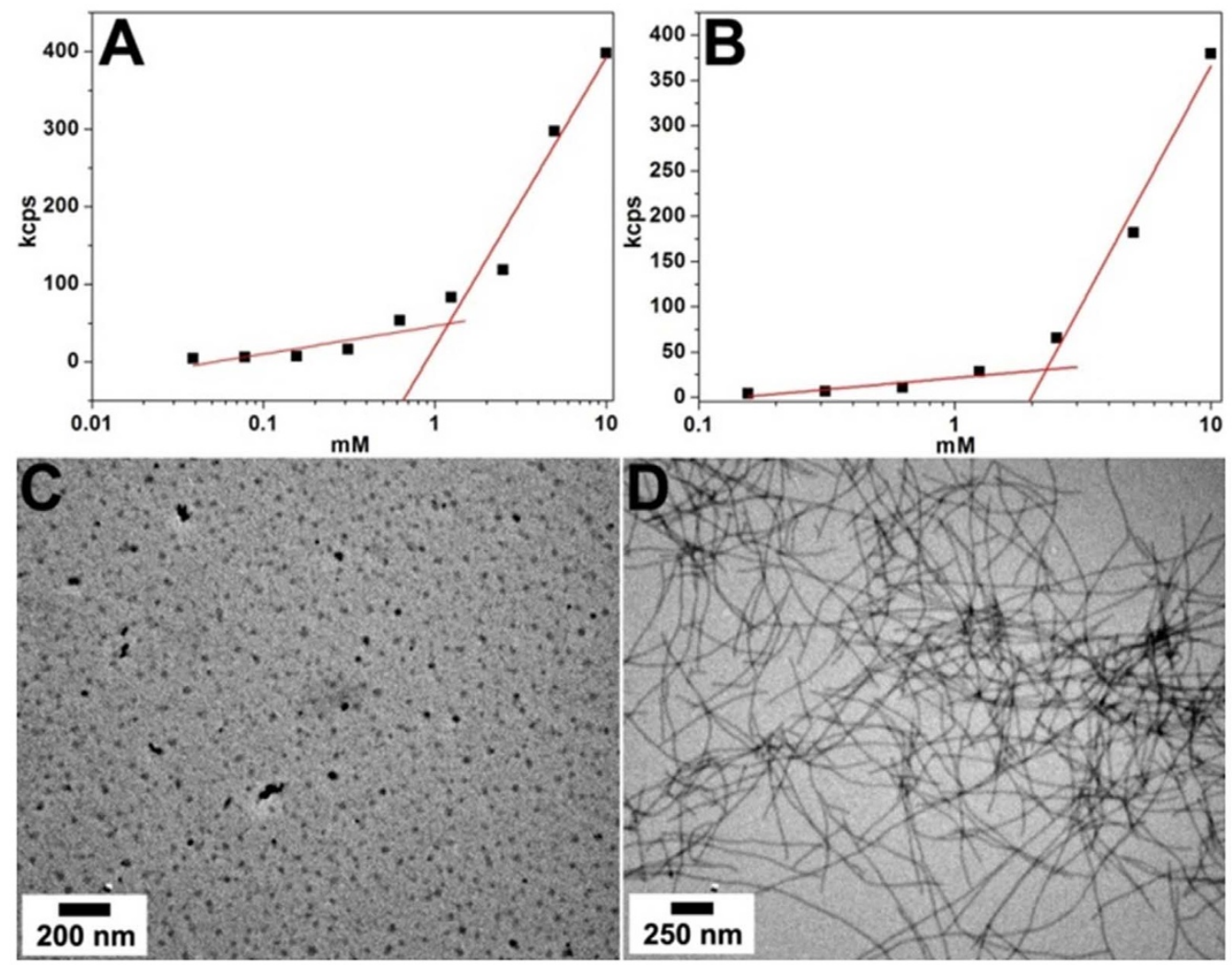

Figure $2 \mid$ Self-assembling properties of choline mimicks. Critical micelle concentration (CMC) values of A) Ada-GFFYKKK' in PBS and B) NapGFFYKKK' in PBS determined by dynamic light scattering (DLS) and transmission electron microscopy (TEM) images of C) Ada-GFFYKKK' in PBS (1.09 wt\%, $\mathrm{pH}=7.4)$ and D) Nap-GFFYKKK' in PBS (1.08 wt\%, $\mathrm{pH}=7.4$ ). 


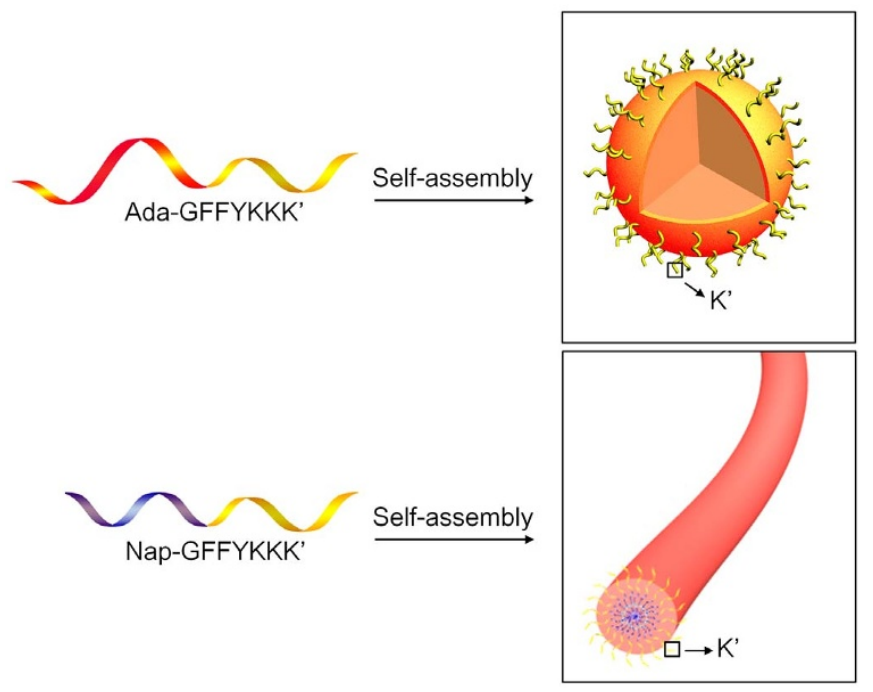

Figure 3 Schematic illustration of proposed formation mechanism of self-assembled nanoparticles and nanofibers from Ada-GFFYKKK' and Nap-GFFYKKK', respectively.

On the other hand, Compound 2 self-assembles into uniform nanofibers with width of around $75 \mathrm{~nm}$ and length of several microns at the concentration of $1.25 \mathrm{mmol} / \mathrm{L}$ (Fig. 2D). This result demonstrates that the self-assembling nanostructure morphology is controllable by simply changing the capping group of the peptide. As compared to the strategy of covalent scaffold synthesis, the peptide selfassembly approach in this study can not only easily achieve multivalency, but also exhibit tunable nanostructure morphology, which would meet the requirements of different biological applications. Fig. 3 depicts the schematic illustration of proposed formation mechanism of self-assembled nanoparticles and nanofibers from Ada-GFFYKKK' and Nap-GFFYKKK', respectively. The molecular hydrogelators of Ada-GFFY and Nap-GFFY favor the peptides self-assemble into nanostructures. As $\mathrm{K}^{\prime}$ is a derivative of $\mathrm{K}$ by its quaternization and is hydrophilic, K's would form the outer layer stabilizing the nanoparticles and nanofibers. As a consequence, the selfassembled nanomaterials possess multivalent $\mathrm{K}$ ' groups at the surface.

Binding affinities of choline mimicks to C-LytA protein. We next produced C-LytA protein to evaluate the interactions of selfassembling 1 and 2 with choline-binding modules in solution. As shown in Fig. 4A, C-LytA is able to be expressed in Escherichia coli and purified to homogeneity with a single band in SDS-PAGE gel $(15.4 \mathrm{kDa})$. The expression yield of C-LytA was $>50 \mathrm{mg} / \mathrm{L}$. Moreover, the analytical gel filtration result (Fig. 4A) and ultracentrifugation result (Fig. 4B) indicate the formation of dimer structure of the C-LytA protein, which agree well with the specific dimerization of the C-LytA module ${ }^{25}$.

After obtaining the pure C-LytA protein, we investigated the interactions between self-assembling peptides and C-LytA by isothermal titration calorimetry (ITC) measurements. As a control, the interaction between C-LytA and Fmok-K' that appears as an amino acid derivative in aqueous solution was also studied. The results depicted in Fig. 5 and Supplementary Fig. S5-S7 revealed that the association constant $\left(K_{\mathrm{a}}\right)$ between C-LytA and self-assembling 1 was $(3.52 \pm$ $0.25) \times 10^{5} \mathrm{M}^{-1}$. In addition, C-LytA and self-assembling 2 possessed two $K_{\mathrm{a}}$ values of $(1.07 \pm 1.12) \times 10^{7}$ and $(1.05 \pm 0.06) \times$ $10^{5} \mathrm{M}^{-1}$, respectively, whereas the $K_{\mathrm{a}}$ between C-LytA and Fmok-K' was $(1.87 \pm 0.22) \times 10^{4} \mathrm{M}^{-1}$. These data illustrate that the $K_{\mathrm{a}}$ values between C-LytA and self-assembling peptides were significantly higher than that between C-LytA and Fmoc-K'. The increased $K_{\mathrm{a}}$ values indicated that the self-assembling peptides with multivalent architectures promoted specific and tight binding to C-LytA modules.

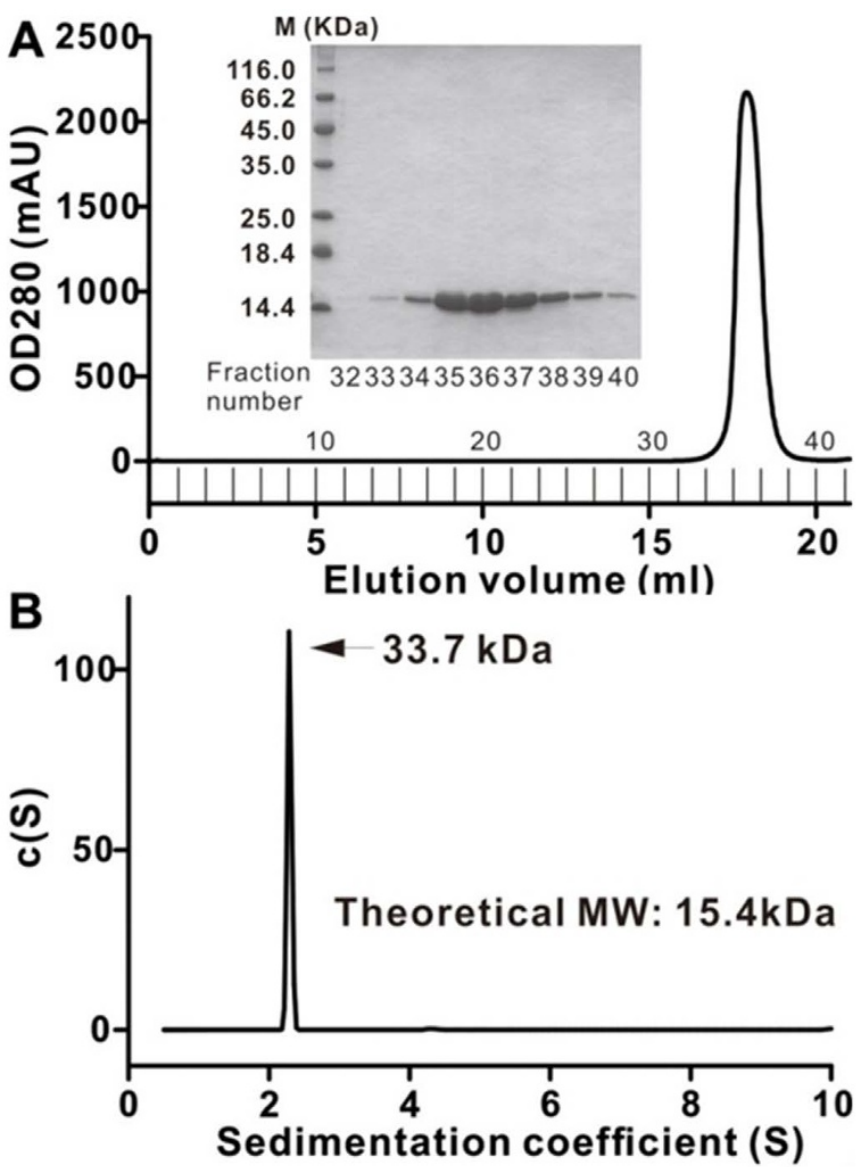

Figure $4 \mid$ Expression and purification of C-LytA protein. A) Analytical gel filtration profile and the SDS-PAGE gel of C-LytA protein and B) $c(S)$ distribution from SV run for C-LytA protein.

The self-assembling Ada-GFFYKKK' and Nap-GFFYKKK' are promising as exogenously choline-mimic inhibitors for suppressing the attachment of choline-binding proteins (e.g., C-LytA dimer) to the pneumococcal cell wall, which could thus reduce the pneumococcal virulence.

\section{Discussion}

We explored a self-assembling choline mimick system, which allows for enhanced binding affinities to choline-binding C-LytA modules.

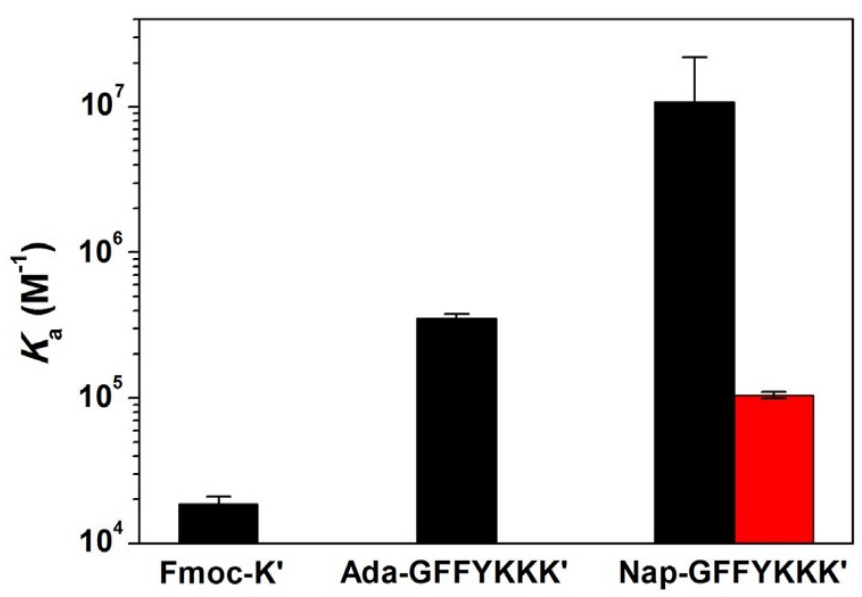

Figure $5 \mid$ Association constant $\left(K_{\mathrm{a}}\right)$ of different compounds determined by ITC. 
The compounds 1 and 2 were firstly designed and synthesized, which could self-assemble into nanoparticles and nanofibers, respectively, yielding multivalent architectures. We had also produced pure CLytA protein and demonstrated its specific dimer structure. Due to the multivalent $\mathrm{K}$ ' groups that could well match the tandem cholinebinding sites in C-LytA, the interactions between C-LytA and selfassembling pepetides were far stronger as compared to the individual peptide Fmoc-K'. Therefore, the self-assembling peptides held great promise as effective inhibitors for reducing the pneumococcal virulence.

\section{Methods}

Chemicals. Fmoc-amino acids were obtained from GL Biochem (Shanghai, China). All the other Starting materials were obtained from Alfa. Chemical reagents and solvents were used as received from commercial sources.

General methods. ${ }^{1} \mathrm{H}$ NMR spectra were obtained on Bruker ARX 400; HR-MS were received from VG ZAB-HS system (England). HPLC was conducted at LUMTECH HPLC (Germany) system using a C18 RP column with $\mathrm{MeOH}(0.05 \%$ of TFA) and water $(0.05 \%$ of TFA) as the eluents; LC-MS was conducted at the Shimadzu LCMS-20AD (Japan) system.

Peptide synthesis. The peptide derivative was prepared by solid phase peptide synthesis (SPPS) using Rink amide resin and the corresponding N-Fmoc protected amino acids with side chains properly protected by a tert-butyl group. The first amino acid Fmoc-K' was loaded on the resin at the C-terminal with the loading efficiency about $0.40 \mathrm{mmol} / \mathrm{g}$. $20 \%$ piperidine in anhydrous $\mathrm{N}, \mathrm{N}$ '-dimethylformamide (DMF) was used during deprotection of Fmoc group. Then the next Fmoc-protected amino acid was coupled to the free amino group using O-(Benzotriazol-1-yl)-N,N,N',N'tetramethyluroniumhexafluorophosphate (HBTU) as the coupling reagent. The growth of the peptide chain was according to the established Fmoc SPPS protocol. At the final step, the N-terminus of the peptides was coupled with 1-Adamantaneacetic acid or Napthelene acetic acid to attach the adamantane or Nap group on the peptides, respectively. After the last coupling step, excessive reagents were removed by a single DMF wash for 5 minutes ( $5 \mathrm{~mL}$ per gram of resin), followed by five steps of washing using DCM for $1 \mathrm{~min}$ ( $5 \mathrm{~mL}$ per gram of resin). The peptide derivative was cleaved using $1 \%$ of trifluoroacetic acid in DCM for ten times (one minute for each time, $5 \mathrm{~mL}$ per gram). All the solutions were combined and concentrated, and then $20 \mathrm{~mL}$ of ice-cold diethylether was added. The resulting precipitate was centrifuged for $10 \mathrm{~min}$ at $2^{\circ} \mathrm{C}$ at $10,000 \mathrm{rpm}$. Afterward the supernatant was decanted and the resulting solid was dissolved in DMSO for HPLC separation.

AdaGFFYKKK'-NH ${ }^{2} \cdot{ }^{1} \mathrm{H}$ NMR (400 MHz, DMSO) $\delta 8.15-7.88(\mathrm{~m}, 7 \mathrm{H}), 7.72(\mathrm{~s}$, $6 \mathrm{H}), 7.40(\mathrm{~s}, 1 \mathrm{H}), 7.27-6.96(\mathrm{~m}, 13 \mathrm{H}), 6.66(\mathrm{~d}, \mathrm{~J}=8.0 \mathrm{~Hz}, 1 \mathrm{H}), 6.65(\mathrm{~s}, 1 \mathrm{H}), 4.45(\mathrm{~s}$, $3 \mathrm{H}), 4.27-4.15(\mathrm{~m}, 3 \mathrm{H}), 3.69(\mathrm{dd}, \mathrm{J}=16.6,5.6 \mathrm{~Hz}, 2 \mathrm{H}), 3.51(\mathrm{dd}, \mathrm{J}=16.6,5.6 \mathrm{~Hz}$, $2 \mathrm{H}), 2.99(\mathrm{~d}, \mathrm{~J}=24.7 \mathrm{~Hz}, 9 \mathrm{H}), 2.73(\mathrm{dd}, \mathrm{J}=40.4,19.3 \mathrm{~Hz}, 7 \mathrm{H}), 2.33(\mathrm{~s}, 1 \mathrm{H}), 1.85(\mathrm{dd}$, $\mathrm{J}=16.2,12.9 \mathrm{~Hz}, 5 \mathrm{H}), 1.59(\mathrm{dd}, \mathrm{J}=34.3,11.4 \mathrm{~Hz}, 23 \mathrm{H}), 1.28(\mathrm{~d}, \mathrm{~J}=34.4 \mathrm{~Hz}, 7 \mathrm{H})$. HR-MS: calc. $\mathrm{M}^{+}=1134.71$, obsvd. $\mathrm{M}^{+}=1134.7029$.

NapGFFYKKK'-NH $2 .{ }^{1} \mathrm{H}$ NMR (400 MHz, DMSO) $\delta 8.16-8.01(\mathrm{~m}, 4 \mathrm{H}), 7.94$ $(\mathrm{dd}, \mathrm{J}=15.5,7.5 \mathrm{~Hz}, 2 \mathrm{H}), 7.88-7.71(\mathrm{~m}, 9 \mathrm{H}), 7.49-7.45(\mathrm{~m}, 2 \mathrm{H}), 7.41(\mathrm{~d}, \mathrm{~J}=6.7 \mathrm{~Hz}$ 2H), 7.25-7.10 (m, 10H), $7.06(\mathrm{~d}, \mathrm{~J}=8.6 \mathrm{~Hz}, 3 \mathrm{H}), 6.66(\mathrm{~d}, \mathrm{~J}=8.4 \mathrm{~Hz}, 2 \mathrm{H})$, $4.47(\mathrm{~s}, 3 \mathrm{H}), 3.64-3.58(\mathrm{~m}, 3 \mathrm{H}), 3.34(\mathrm{~s}, 19 \mathrm{H}), 2.79-2.66(\mathrm{~m}, 7 \mathrm{H}), 1.67(\mathrm{~s}, 5 \mathrm{H}), 1.53$ (s, $7 \mathrm{H}), 1.28(\mathrm{~d}, \mathrm{~J}=36.8 \mathrm{~Hz}, 7 \mathrm{H})$. HR-MS: calc. $\mathrm{M}^{+}=1126.65$, obsvd. $\mathrm{M}^{+}=1126.6419$

Critical micelle concentration (CMC) measurements. The CMC values of peptides in PBS ( $\mathrm{pH}=7.4$ ) was determined measuring samples of different concentrations obtained by the scattered light intensity. All samples were prepared by filtering about $1 \mathrm{~mL}$ of solution with a $0.45 \mu \mathrm{m}$ Millipore filter into a clean scintillation vial and then characterized at room temperature. Dynamic Light Scattering (DLS) was performed on a laser light scattering spectrometer (BI-200SM) equipped with a digital correlator $(\mathrm{BI}-9000 \mathrm{AT})$ at $659 \mathrm{~nm}, 90$ degree angle under room temperature $\left(25^{\circ} \mathrm{C}\right)$.

Transmission electron microscopy (TEM) observations. TEM samples ( $4 \mathrm{mg} \mathrm{mL}^{-1}$ Ada-GFFYKKK' $-\mathrm{NH}_{2}$ and NapGFFYKKK'- $\mathrm{NH}_{2}$ ) were prepared at $25^{\circ} \mathrm{C}$ in PBS. A micropipet was used to load $5 \mu \mathrm{L}$ of sample solution to a carbon coated copper grid. The excess solution was removed by a piece of filter paper. Uranyl acetate was used to stain the samples. The samples were dried overnight in a desicator and then conducted on a Tecnai G2 F20 system, operating at $200 \mathrm{kV}$.

Protein expression and purification. To obtain the C-LytA protein, the expression plasmid was constructed and then transformed into Escherichia coli strain BL21(DE3). The cells harboring the expression plasmid were grown in LB medium at $37^{\circ} \mathrm{C}$ until the $\mathrm{OD}_{600}$ reached 0.6 and then induced with $0.3 \mathrm{mM}$ IPTG at $16^{\circ} \mathrm{C}$ for 16-18 h. After being spun at 5,000 rpm for $15 \mathrm{~min}$, the E. coli cells were resuspended in $\mathrm{H}_{25} \mathrm{~N}_{150}$ buffer(25 mM HEPES pH 7.0, $\left.150 \mathrm{mM} \mathrm{NaCl}\right)$. After the cells were lysed by sonication, the lysates were centrifuged at $18,000 \mathrm{rpm}$ for $30 \mathrm{~min}$. The supernatant was loaded onto a $\mathrm{Q}$ sephatose column that was equilibrated with $\mathrm{H}_{25} \mathrm{~N}_{150}$ buffer and washed with $\mathrm{H}_{25} \mathrm{~N}_{1500}$ buffer(25 mM HEPES pH 7.0, $1500 \mathrm{mM}$
$\mathrm{NaCl}$ ) for two times to remove most other proteins. Finally, the C-LytA protein was eluted by $20 \mathrm{~mL} \mathrm{H}_{25} \mathrm{~N}_{150}$ buffer contained $2 \%$ choline and was dialysis into PBS buffer $\left(137 \mathrm{mM} \mathrm{NaCl}, 2.7 \mathrm{mM} \mathrm{KCl}, 8 \mathrm{mM} \mathrm{Na}_{2} \mathrm{HPO}_{4}\right.$, and $2 \mathrm{mM} \mathrm{KH}_{2} \mathrm{PO}_{4}$ ) to remove the choline.

Analytical size-exclusion chromatography. Analytical size exclusion chromatography was carried out using Superdex 200 10/300 GL (GE Healthcare), the column was equilibrated with 1 column volume of PBS buffer. $1 \mathrm{~mL}$ of C-lytA protein was injected onto the column, and eluted with the same equilibrated buffer at a flow rate of $0.5 \mathrm{~mL} / \mathrm{min}$ (AKTA purifier, GE Healthcare, USA). The eluent fractions were collected between 16 and $20 \mathrm{~mL}$. The protein was fractionated and analyzed by $20 \%$ SDS-PAGE.

Analytical ultracentrifugation. Sedimentation velocity (SV) experiments were performed in a Beckman Coulter XL-I analytical ultracentrifuge (Beckman Coulter) using double-sector centerpieces and sapphirine windows. Before the experiments, the proteins were transferred to PBS buffer by Superdex 200 10/300 GL column (GE Healthcare). Proteins at absorbances of $4.4 \mathrm{~A}(1 \mathrm{mg} / \mathrm{mL})$ at $280 \mathrm{~nm}$ were loaded into double-sector cells for SV experiments, which were conducted at $42,000 \mathrm{rpm}$ at $10^{\circ} \mathrm{C}$ and with absorbance detected at $280 \mathrm{~nm}$. The buffer composition (density and viscosity) and protein partial specific volume (V-bar) were obtained with the SEDNTERP program (available through the Boston Biomedical Research Institute). The SV data were analyzed using the SEDFIT programs.

Isothermal titration calorimetry (ITC) measurements. ITC measurements were carried out on a MicroCal ${ }^{\mathrm{TM}}$ iTC200(GE Healthcare) in PBS buffer $(137 \mathrm{mM} \mathrm{NaCl}$, $2.7 \mathrm{mM} \mathrm{KCl}, 8 \mathrm{mM} \mathrm{Na}_{2} \mathrm{HPO}_{4}$, and $2 \mathrm{mM} \mathrm{KH}_{2} \mathrm{PO}_{4}$ ) at $16^{\circ} \mathrm{C}$. The peptides were dissolved in the same buffer mentioned above and adjusted to $\mathrm{pH} 7.4$. Both peptide and protein solutions were degassed by being spun at 13,000 rpm for $15 \mathrm{~min}$. To measure the association constant of C-lytA with Fmoc-Lys $\left(\mathrm{Me}_{3}\right)$ (Fmoc-K') or peptide (Ada-GFFYKKK'-NH $\mathrm{N}_{2}$ and Nap-GFFYKKK'-NH $\mathrm{N}_{2}$ ), an initial injection $(0.4 \mu \mathrm{L})$ followed by 19 injections $(2 \mu \mathrm{L})$ peptide into the calorimeter cell, which was completely filled with protein solution, were collected at $120 \mathrm{~s}$ intervals while being stirred at $1000 \mathrm{rpm}$. The titration data and binding plot were analyzed using MicroCal Origin software with one-site binding model or two-site binding model.

1. Eskola, J. et al. Efficacy of a pneumococcal conjugate vaccine against acute otitis media. N. Engl. J. Med. 344, 403-409 (2001).

2. Tan, T. Q. Pneumococcal infections in children. Pediatr. Ann. 31, 241-247 (2002).

3. Huang, S. S. et al. Healthcare utilization and cost of pneumococcal disease in the United States. Vaccine 29, 3398-3412 (2011).

4. Pilishvili, T. et al. Sustained reductions in invasive pneumococcal disease in the era of conjugate vaccine. J. Infect. Dis. 201, 32-41 (2010).

5. Tomasz, A. Choline in the cell wall of a bacterium: novel type of polymer-linked choline in pneumococcus. Science 157, 694-697 (1967).

6. Bergmann, S. \& Hammerschmidt, S. Versatility of pneumococcal surface proteins. Microbiology 152, 295-303 (2006).

7. Hernández-Rocamora, V. M. et al. Multivalent choline dendrimers as potent inhibitors of pneumococcal cell-wall hydrolysis. Angew. Chem. Int. Ed. 48, 948-951 (2009).

8. Brown, S., Santa Maria Jr, J. P. \& Walker, S. Wall teichoic acids of gram-positive bacteria. Annu. Rev. Microbiol. 67, 10.1146/annurev-micro-092412-155620 (2013).

9. Fernández-Tornero, C., López, R., García, E., Giménez-Gallego, G. \& Romero, A. A novel solenoid fold in the cell wall anchoring domain of the pneumococcal virulence factor LytA. Nat. Struct. Biol. 8, 1020-1024 (2001).

10. Maestro, B., Santiveri, C. M., Jiménez, M. A. \& Sanz, J. Structural antonomy of a $\beta$ hairpin peptide derive from the pneumococcal choline-binding protein LytA. Protein Eng. Des. Sel. 24, 113-122 (2011).

11. López, R. Pneumococcus: the sugar-coated bacteria. Int. Microbiol. 9, 179-190 (2006).

12. Briese, T. \& Hakenbeck, R. Interaction of the pneumococcal amidase with lipoteichoic acid and choline. Eur. J. Biochem. 146, 417-427 (1985).

13. Ribes, S. et al. Multivalent choline dendrimers increase phagocytosis of Streptococcus pneumoniae R6 by microglial cells. Chemotherapy 59, 138-142 (2013).

14. Sanz, J. M., Lopez, R. \& García, J. L. Structural requirements of choline derivatives for 'conversion' of pneumococcal amidase. A new single-step procedure for purification of this autolysin. FEBS Lett. 232, 308-312 (1988).

15. Maestro, B., González, A., García, P. \& Sanz, J. M. Inhibition of pneumococcal choline-binding proteins and cell growth by esters of bicyclic amines. FEBS J. 274, 364-376 (2007)

16. Medrano, F. J. et al. Structural characterization of the unligated and cholinebound forms of the major pneumococcal autolysin LytA amidase: conformational transitions induced by temperature. J. Biol. Chem. 271, 29152-29161 (1996).

17. Barnard, A. \& Smith, D. K. Self-assembled multivalency: dynamic ligand arrays for high-affinity binding. Angew. Chem. Int. Ed. 51, 6572-6581 (2012).

18. Badjić, J. D., Nelson, A., Cantrill, S. J., Turnbull, W. B. \& Stoddart, J. F. Multivalency and cooperativity in supramolecular chemistry. Acc. Chem. Res. 38, 723-732 (2005) 
19. Boncheva, M. \& Whitesides, G. M. Making things by self-assembly. MRS Bull. 30 , 736-742 (2005).

20. Yang, Z. M., Liang, G. L. \& Xu, B. Enzymatic hydrogelation of small molecules. Acc. Chem. Res. 41, 315-326 (2008).

21. Miao, X. M. et al. Switchable catalytic activity: selenium-containing peptides with redox-controllable self-assembly properties. Angew. Chem. Int. Ed. 52, 7781-7785 (2013).

22. Wang, H. M. et al. Enzyme-triggered self-assembly of a small molecule: a supramolecular hydrogel with leaf-like structures and an ultra-low minimum gelation concentration. Nanotechnology 21, 225606 (2010).

23. Wang, H. M. et al. Enzyme-assisted formation of nanosphere: a potential carrier for hydrophobic compounds. Nanotechnology 21, 155602 (2010).

24. Yang, C. H. et al. Responsive small molecular hydrogels based on adamantinepeptides for cell culture. J. Phys. Chem. B 116, 633-638 (2012).

25. Usobiaga, P. et al. Structure organization of the major autolysin from Streptococcus pneumonia. J. Biol. Chem. 271, 6832-6838 (1996).

\section{Acknowledgments}

This work was supported by the National Natural Science Foundation of China (51373079 and 81301311).

\section{Author contributions}

Z.Y. and D.D. designed the project; D.D., J.L. and Z.Y. wrote the manuscript and discussed the results; Y.S. and X.Z. did the syntheses and characterizations; H.Z. expressed and characterized the protein; J.W. performed the MTT assay.

\section{Additional information}

Supplementary information accompanies this paper at http://www.nature.com/ scientificreports

Competing financial interests: The authors declare no competing financial interests. How to cite this article: Shi, Y. et al. Self-assembling choline mimicks with enhanced binding affinities to C-LytA protein. Sci. Rep. 4, 6621; DOI:10.1038/srep06621 (2014).

This work is licensed under a Creative Commons Attribution-NonCommercialNoDerivs 4.0 International License. The images or other third party material in this article are included in the article's Creative Commons license, unless indicated otherwise in the credit line; if the material is not included under the Creative Commons license, users will need to obtain permission from the license holder in order to reproduce the material. To view a copy of this license, visit http:// creativecommons.org/licenses/by-nc-nd/4.0/ 